\title{
Effect of Learning Motivation, Family Factor, School Factor, and Community Factor on Student Learning Outcomes on Productive Subjects
}

\author{
Oktaviani Pratiwi Wijaya \\ Imam Bukhori \\ Education Administration Offices State University of Malang \\ Email: oktaprawija@gmail.com; imam.bukhori.fe@um.ac.id
}

\begin{abstract}
This study aims to determine: (1) conditions of learning motivation, family factors, school factors, community factors and learning outcomes; (2) the influence of learning motivation on learning outcomes; (3) the influence of family factors on learning outcomes; (4) the influence of school factors on learning outcomes; (5) the influence of community factors on learning outcomes; (6) the influence of learning motivation, family factors, school factors and community factors on learning outcomes. The population in this study is all students of class X Class Office Administration Study Program as many as 109 students, the sample used as many as 86 students using proportional random sampling technique. Data analysis techniques used are descriptive statistics and multiple linear regression analysis. The results showed that: (1) learning motivation can be classified well, the family factor can be classified very well, school factor can be classified well, society factor can be classified well; (2) learning motivation has no significant effect on learning outcomes; (3) family factors partially have a positive and significant effect on learning outcomes; (4) school factors partially have a positive and significant impact on learning outcomes; (5) community factors partially have a positive and significant impact on learning outcomes; (6) learning motivation, family factor, school factor and community factor simultaneously have a positive and significant impact on learning outcomes.
\end{abstract}

Keywords: learning motivation, family factor, school factor, community factor, learning outcomes

Education has an important role in creating quality human resources to become the next generation of a nation that is able to face the problems that exist in an increasingly changing era. The creation of a quality successor generation must be balanced with high-quality education. There are several components that support the creation of quality education, one such component is the teacher. Education in schools is basically organized through the process of teaching and learning. If the learning process is done well and in accordance with the rules, then the results of learning will also be good. Achievement or success of the learning objectives of one can be seen from the learning achievement of learners.

Learning outcomes possessed learners become benchmarks to determine the level of learning success of learners. Learning outcomes are patterns of actions, values, understandings, attitudes, appreciation and skills (Suprijono, 2012: 5). To encourage the achievement of quality learning outcomes learners must be aware and have a strong will that the motivation from within oneself is one of the principles that affects the learning outcomes of learners, in addition to family factors, school factors and community factors also greatly affect the learning outcomes of learning.

Hamalik (2008: 158) states that "The motivation to learn is a change of energy from a person (person) that is characterized by the emergence of feelings and reactions to achieve goals". Motivated learners will have a strong desire to carry out teaching and learning activities well. Motivation to learn is a change of energy from the learners themselves are characterized by the emergence of feelings and reactions to achieve the 
desired goals. The existence of learning motivation learners will be more active when learning in class. So with so the results of learning that will be good. As Uno (2011: 28) says, "A child who has been motivated to learn something, will try to learn it well and diligently, in hopes of getting good results".

The family factor is the nearest environment in the learner to get an education because the environment has been formed since the beginning of the birth to the world. Shah (2014: 135) states: "Parents' traits, family management practices, family tensions, and family demography (home location) can all have a good or bad impact on learning activities and student outcomes." The way parents educate, home atmosphere, understanding parents are examples of indicators that affect learning. Slameto (2010: 63) reveals "In order for children to learn well should be created atmosphere of a quiet and peaceful home in addition to children feel at home, children can also learn well". Then it can be concluded that whether or not the behavior of learners, whether or not learning in the family environment depends on how the child is raised and educated in a family environment.

In addition to family factors, factors that influence the success of learning is the school factor. Shah (2014: 135) states "The social environment of schools such as teachers, educational staff (headmasters and representatives) and classmates can influence a student's learning spirit". School is one of the factors that affect the growth and development of learners, especially in terms of intelligence.

The last factor that influences the learning outcomes of learners is the community factor. Community factor is the environment of residence, association and lifestyle of the community around the residence. The community environment that also influences the learning of learners is the activities of learners in society, mass media, social friends and community activities (Slameto 2010: 70). The community environment is included in the non-formal learning environment because the community environment is outside the school. Shah (2014: 135) states "The condition of people in slum-stricken neighbourhoods and unemployed children, for example, will greatly affect student learning activities".

Based on the background and the formulation of the problem that has been described, the alternative hypothesis ( $\mathrm{Ha}$ ) is formulated as follows:

Ha1: There is a positive and significant influence on the motivation of learning on the learning outcomes of students of class X on the subjects Productive Department of Administration Office at SMKN 2 Blitar.

Ha2: There is a positive and significant influence between family factors on the learning outcomes of students of class X on subjects Productive Department of Administration Office at SMKN 2 Blitar.

Ha3: There is a positive and significant influence between school factors on the learning outcomes of class X students on Productive subjects Department of Office Administration at SMKN 2 Blitar.

Ha4: There is a positive and significant influence on the factors of society on the learning outcomes of students of class X on subjects Productive Department of Administration Office at SMKN 2 Blitar.

Ha5: There is a positive and significant influence between learning motivation, family factors, school factors and community factors on the learning outcomes of class $\mathrm{X}$ students in Productive subjects Department of Office Administration at SMKN 2 Blitar. 


\section{METHOD}

In this study, researchers used a quantitative approach, while the type of this study using descriptive correlational. The description is used to describe, analyze, and interpret data from the variables of learning motivation, family factors, school factors, and community factors on student learning outcomes. Correlational used to know whether there is a correlation between an independent variable that is learning motivation (X_1), family factor (X_2), school factor (X_3), and society factor (X_4) with dependent variable that is learning result (Y). The population in this study were all students of class X SMKN 2 Blitar Office Administration Study Program as many as 109 students with samples used as many as 86 students. The sample used in this research using Slovin formula (Suharsaputra 2014: 119) Sampling is done by proportional random sampling technique that is done by lottery. The lottery number according to the student attendance number of each class is then drawn as many as the number of samples per class.

The technique of taking data using documentation and questionnaire with five alternative answers according to Likert scale. Primary data in this research is obtained from the statement in accordance with the research variables of learning motivation, family factors, school factors, and community factors, while secondary data derived from the value of report cards related to the value of knowledge and skills value on the subjects Productive learners class X semester odd. This study uses descriptive statistics to describe the learning motivation, family factors, school factors, and community factors, and learning outcomes of productive subjects. Regression analysis there are several assumptions that must be met so that the resulting regression equation will be valid if used to draw conclusions. In this study, the researchers used normality test, multicollinearity test, and heteroscedasticity test. Then the hypothesis test in this research used multiple linear regression or test to know the partial influence between learning motivation (X_1), family factor (X_2), school factor (X_3), and community factor (X_4) as an independent variable with learning result $Y$ ) as the dependent variable. In addition to the $t$ test, this study uses $F$ test to determine the effect simultaneously between learning motivation (X_1), family factor (X_2), school factor (X_3), and community factor $\left(X_{-} 4\right)$ together with learning outcome $(Y)$. In order to obtain accurate data, this research uses the help of SPSS program.

\section{DISCUSSION \& RESULT}

The results of the respondents' description show that most of the respondents are female, and each class has the same number of learners. The majority of respondents have 3 siblings, 16 years of age and home range to school spread up to $<12 \mathrm{~km}$. The majority of the last education that Father and Mother have completed is the average elementary and junior high school, the majority of Father's work is entrepreneurship, farmers, breeders and others, while the majority of Mother's job is as a housewife. The average monthly income for an average parent is $\leq 2,000,000$.

After doing research on the sample of respondents as many as 86 students obtained a description of learning motivation, family factors, school factors, community factors and learning outcomes. Motivation to learn has an average score of 4.19 so it can be concluded that the motivation to learn entered the category well. Family factors have an average score of 4.21 so it can be concluded that family factors fall into the category very well. The school factor has an average score of 3.87 so it can be concluded that 
school factors fall into the good category. The community factor has an average score of 4.04 so it can be concluded that community factors are included in the good category. Learning outcomes for most learners have met the Minimum Exhaustiveness Criteria (KKM) so that it can be concluded that the learning outcomes of learners are high.

Prior to analysis, the data were tested by using classical assumption test consisting of normality test, multicollinearity test, and heteroscedasticity test. The results obtained are the data used in this study normal distribution, no symptoms of multicollinearity, and no heteroskedasticity disorder. So it can be concluded that the regression equation deserves to be used for further research.

Regression equation has a constant value of 68.285 means if the motivation to learn, family factors, school factors, and community factors are 0 then the learning outcome is worth 68.285 . The value of regression coefficient of learning motivation (X1) is 0,889 , it means that every variable of learning motivation increase one unit, it will increase learning motivation variable equal to 0,889 with assumption another variable is a fixed value. The value of regression coefficient variable of family factor (X2) is 0,954 , it means that every family factor variable increase one unit, it will increase family factor variable equal to 0,954 with assumption another variable is a fixed value. The value of regression coefficient factor of school factor (X3) is 1,177, it means that every variable of school factor increase one unit, it will increase school factor variable equal to 1,177 with assumption another variable is a fixed value. The value of regression factor coefficient of community factor (X4) is 0,810 , it means that every variable of society factor increase one unit, it will increase society factor variable equal to 0,810 with assumption other variables have a fixed value. Also known as Adjusted R Square of 0.369 . It shows the percentage of contribution of the influence of learning motivation, family factor, school factor, and community factor $36,9 \%$ while the rest equal to 63,1 influenced by other variables such as interest, talent, level of intelligence and others, which is not within the scope of this research.

Tabel 1. Pengaruh Motivasi Belajar, Faktor Keluarga, Faktor Sekolah, dan Faktor Masyarakat secara parsial terhadap Hasil Belajar.

\begin{tabular}{lccclc}
\hline \multicolumn{1}{c}{ Variabel Bebas } & $\mathbf{t}_{\text {tabel }}$ & $\mathbf{t}_{\text {hitung }}$ & Sig. & \multicolumn{1}{c}{ Keterangan } \\
\hline Motivasi Belajar & 1,987 & 1,851 & & $\begin{array}{l}\mathrm{H}_{0} \text { diterima, } \\
\text { ditolak }\end{array}$ & $\mathrm{H}_{\mathrm{a}}$ \\
Faktor Keluarga & 1,987 & 2,825 & 0,068 & $\begin{array}{l}\mathrm{H}_{0} \text { ditolak, } \mathrm{H}_{\mathrm{a}} \\
\text { diterima }\end{array}$ \\
Faktor Sekolah & 1,987 & 2,713 & 0,006 & $\begin{array}{l}\text { Ho ditolak, } \mathrm{H}_{\mathrm{a}} \\
\text { diterima }\end{array}$ \\
Faktor Masyarakat & 1,987 & 2,344 & 0,008 & $\begin{array}{l}\mathrm{H}_{0} \text { ditolak, } \mathrm{H}_{\mathrm{a}} \\
\text { diterima }\end{array}$ \\
\hline Variabel terikat: Hasil Belajar & & & 0,002 & &
\end{tabular}

Based on Table 1 it is known that the learning motivation of tcount 1.851 and ttabel 1.987 with significance obtained of 0.068 and significance level of 0.05 (5\%). This means tcount $1,851<$ ttabel 1,987 . While significance obtained $0,068 \leq$ level of significance $0,05(5 \%)$, so there is no significant influence on motivation learn to result learn. The family factor of count 2,825 and table 1,987 with significance obtained equal to 0,006 and significance level 0,05 (5\%). It means tcount 2,825> ttable 1,987. While significance gained $0,006 \leq$ level of significance $0,05(5 \%)$, so there is positive and significant influence between family factor to result learn. School factor of tcount 2,713 and ttabel 1,987 with significance obtained at 0,008 and significance level 0,05 (5\%). It 
means thitung 2,713> ttable 1,987. While the significance obtained $0,008 \leq$ significance level of $0.05(5 \%)$, so there is a positive and significant influence between school factors on learning outcomes. Community factor of tcount 2,344 and ttabel 1,987 with significance obtained equal to 0,022 and significance level $0,05(5 \%)$. This means thitung 2,344> ttable 1,987. While the significance obtained $0,002 \leq$ level of significance $0,05(5 \%)$, so there is positive and significant influence between society factor to result learn.

Tabel 2. Pengaruh Motivasi Belajar, Faktor Keluarga, Faktor Sekolah, dan Faktor Masyarakat secara simultan terhadap Hasil Belajar

\begin{tabular}{llccccc}
\hline Model & & Sum of Squares & Df & Mean Square & F & Sig. \\
\hline 1 & Regression & 176,188 & 4 & 44,047 & 13,411 & $0,000^{\mathrm{b}}$ \\
& Residual & 266,044 & 81 & 3,284 & & \\
& Total & 442,233 & 85 & & & \\
\hline
\end{tabular}

Based on Table 2 it is known that the value of Fcount 13.411 with Ftabel 2.48 and the significance obtained at 0.000 with a significance level of 0.05 (5\%). It means Fcount 13.411> Ftable 2.48. While the significance obtained $0.000 \leq$ level of significance 0.05 . So that there is a positive and significant influence on learning motivation, family factors, school factors, and community factors on learning outcomes

\section{Discussion}

Description of the motivation variables of learners consists of 5 indicators that are the desire and desire succeed, the awards in learning, the activities of interest in learning, the purpose of imaging achieved, and the persistence in learning. Based on the results of research conducted by researchers to 86 respondents on the indicator of the desire and desire successfully obtained the average results of respondents in the category very well. So it can be concluded that the motivation of learners on subjects Productive class $\mathrm{X}$ SMK Negeri 2 Blitar is in the high category. This means that learners have the desire to get good grades and have a sense of confidence in the ability possessed by learners. This is consistent with the opinion expressed by Tuncel (2015: 2575) which states that learners with high self-esteem will have better learning outcomes than learners who have low self-esteem. Learners will learn the spirit if given a gift and motivated learners want to get the rank or champion in order to get the award. in accordance with the opinion expressed by Hoffmann (2009: 843) revealed that teachers who give real appreciation in their class. Learners have a goal to gain knowledge. Learners mostly have high motivation as earnest because they want to get good grades, active learners at the time of learning and peer

Description of the factors variable family of learners consists of 4 indicators that are how to educate parents, home atmosphere, family economic conditions, and understanding of parents who entered the category very well. Based on the results of research conducted by researchers to the respondents can be concluded how parents educate on the subjects Productive class X SMK Negeri 2 Blitar obtained the average results of respondents in the category very good answer. This means that learners are always educated parents well at home. parents of learners can meet basic daily needs. Basic daily needs such as food needs, pocket money, uniforms, school equipment, equipment to decorate learning and so forth can be met by parents of learners. When learners learn parents understand so as not to ask to do other work. When not 
enthusiastic learners are given the encouragement and understanding of parents that learning and education are important. This is in accordance with the opinion expressed by Mustafa et al (2010: 422) that with the support of parents in the form of understanding and empathy parents become a source of strength for learners who have difficulty in learning so that support can strengthen themselves, learners.

Description of factor variable of school students consists of 7 indicator that is teaching method, teacher relation with the student, student relation with the student, school discipline, lesson tool, building condition, and learning method entered in the good category. This means that the relationship of interaction between students and teachers running smoothly. So if the interaction between teachers and learners run smoothly does not rule out the possibility that the learning process will be smooth. This is in accordance with the opinion expressed by Sanchez et al (2013: 116) states that the willingness to learn learners will increase if the teacher shows the attitude of care and appreciate the ability of learners. The relationship of interaction between learners with classmates or peers in a harmonious state there is no dispute. Provide sanctions given by BP teachers to learners against violations committed in schools. The classroom of learners has a chairs table that is neat and comfortable when used learners to learn. In addition to the classroom chairs are conducive to the classroom away from the crowd also affects the comfort to learn learners. This is in line with the opinion expressed by Schneider (2002: 16) that school facilities affect the learning process such as clean air, good light, and a quiet, comfortable, and safe learning environment.

Description of the factor variable of the learner's community consists of 4 indicators of student activity in the community, mass media, social friends, and forms of community activities. Based on the results of research conducted by researchers to the respondents class X SMK Negeri 2 Blitar obtained the average results of respondents in the category good answer. This means that in the community of learners follow activities such as teenage mosques and youth cadets. Mass media such as newspapers, radio, television, internet etc. can easily be used learners to obtain information. Information obtained learners can be general knowledge, lessons or social media. This is in accordance with the opinion expressed by Florescu (2014: 352) that information in mass media is presented with ease and intellectually stimulating that can be very effective in forming the necessary women, but must be used properly and efficiently. no fights. Which means the community environment consisting of educated society there is no thief or robber. Peers who are the home learners give a good influence as invited to study after school. This is in accordance with the opinion put forward by Saputro \& Pardiman (2012: 94) that the environment of peers affects the learning achievement of learners.

Learning outcomes were obtained from report cards covering productive subjects of Archives, Correspondence, Digital Simulation and Office Automation. The limitations in the learning outcomes are the values obtained by the researchers instead of the original grades of the report cards, but the average outcomes of those subjects consist of the value of knowledge and skill values. Based on the result of the research, it is found that the students' learning outcomes on the subjects of Productive class X SMK Negeri 2 Blitar are good, it is proved by all students of class X APK 1, APK 2, and APK 3 get value not less than the value of KKM (Criteria of Completeness Minimum) is 80 .

Based on the results of data analysis there is no significant influence on the motivation of learning on the learning outcomes of students class $\mathrm{X}$ on subjects Productive Department of Administration Office at SMKN 2 Blitar. This means that even though learners have a higher learning motivation then it can happen does not affect the 
high learning outcomes that learners get. This can happen because learning motivation is not the only variable that can affect learning outcomes. The existence of other variables such as confidence, interest, talent, EQ, how to learn and others that can affect learning outcomes. But in this study did not discuss these variables.

So the motivation to learn does not affect the high low learning outcomes learners obtained. This research is in contrast to Herera's research (2013: 193) which states that the more fit the motivation that the students have, the higher it will be to achieve the objectives or learning outcomes. Highly motivated learners may not necessarily have higher learning outcomes than low motivated learners. With the high motivation but no effort is given to do the learning activities will not affect the results of learning with maximum results. So the motivation to learn cannot stand alone to influence learners' learning outcomes.

The results of this study contradict with previous research conducted by David (2012: 253) that the motivation to learn a positive and significant impact on learning outcomes. Other research is contradictory done by Rahayu (2013: 12) that the motivation to learn a significant effect on learning outcomes. In addition, research conducted by Sholihah \& Kurniawan (2016: 4) also suggests that the motivation to learn a significant effect on learning outcomes.

Based on the results of data analysis there is a positive and significant influence between family factors on learning outcomes of students class X on subjects Productive Department of Administration Office at SMKN 2 Blitar. This means that the increasing or better the family factor that the learners have, the learning outcomes obtained by learners will be more optimal. This is in accordance with research conducted by Hasanah (2014: 10) which states that students who have a very good family environment has high learning results and vice versa learners whose family is not good to have low learning outcomes. The presence of supervision by parents to learners such as home study or the success of learning that has been obtained at school. Supervision will affect the learning outcomes obtained by learners. Nguon (2012: 2013) that the supervision of parents affects the learning outcomes of learners.

The results of this study are in line with previous research conducted by Khafid \& Suroso (2007: 200) that the family environment affects the learning outcomes. The results of this study are also in harmony with previous research conducted Hasanah (2014: 10) that there is a significant influence on the family environment on learning outcomes.

Based on the results of data analysis there is a positive and significant influence between school factors on the learning outcomes of students class $\mathrm{X}$ on subjects Productive Department of Administration Office at SMKN 2 Blitar. This means that the increasing or better the school factor that the learners have, the learning outcomes obtained by learners will be more optimal. This is supported by previous research Mukhlas et al (2014: 15) the better the school environment will also increase student learning outcomes and vice versa, the worse the school environment the student learning outcomes will also be lower. All that is in school will certainly support the learning outcomes of good learners such as discipline, relationships between friends, methods, facilities and infrastructure and so forth. The results of this study in accordance with the opinion Kartika (2013: 5) states that the school environment plays an important role in the development of learning learners.

The results of this study in accordance with previous research conducted by Mukhlas et al (2014: 14) stating that the school environment has a significant effect on learning outcomes. Other research results in accordance with this research are research 
conducted by Adeyemo (2012: 25) that there is a significant influence on the school environment on learning outcomes.

Based on the results of data analysis there is a positive and significant influence on the community environment on the learning outcomes of students class $\mathrm{X}$ on subjects Productive Department of Administration Office at SMKN 2 Blitar. This means that the increasing or better the community factors that students have, the learning outcomes obtained by learners will be more optimal. Community environment also supports student learning outcomes if the environment of learners good, and if the environment does not support learning activities then learners will be disturbed. In the meantime, the friend mingles learners participate in influencing the result of learning, indirectly learners will more imitate or imitate her friend, so if the friend associates good personality then will make the student follow him. As stated by Ahmadi \& Supriyono (2008: 92) suggests that friends mingle influence is very large and more quickly entered into the soul of learners.

The results of this study are consistent with the results of previous research conducted by Sholihah \& Kurniawan (2016: 4) stating that the learning environment affects the learning outcomes of learners. Kartika (2013: 11) which states that the learning environment has a significant effect on the learning outcomes that at the same time there is a significant relationship between the community environment and learning outcomes.

Based on the results of data analysis there is a positive and significant influence between learning motivation, family factors, school factors, and societal factors simultaneously to the learning outcomes of class $\mathrm{X}$ students on Productive subjects Department of Office Administration at SMKN 2 Blitar. This means that together the motivation to learn, family factors, school factors, and community factors affect student learning outcomes. Learning motivation and the three learning environment factors cannot be separated from each other. with the motivation to learn learners will have a clear purpose in the learning process so that when learners do activities that will make the learning outcome decreased learners will remember motivation he held to get good learning outcomes so far.

As stated by Prawira 2012: 320) said that the motivation of an effort to improve activities in achieving a particular goal, including learning activities. This is in line with David's opinion (2012: 250) that motivation to learn is all the symptoms contained in the stimulation of actions to generate, maintain and control the basic impetus in learners in achieving learning goals. In addition to these learning motivations with the support of factors that influence learning such as family factors, school factors, and community factors will certainly support the learning process. As explained by Tirtarahardja \& Sulo (2005: 187) that education is a complex process and involves various parties, especially families, schools, and communities as an educational environment known as educational trips. These three factors, either individually or collectively, are important factors for educational purposes

The results of this study support the results of previous research conducted by Sandra et al (2013: 25) which indicates that there is a significant relationship between the learning environment with learning outcomes. In addition, other research results in accordance with the research. 


\section{CONCLUSION \& SUGGESTIONS}

\section{Conclusion}

The results of this study indicate that: (1) learning motivation can be classified well, family factors can be classified very well, school factors can be classified well, community factors can be classified either; (2) learning motivation has no significant effect on learning outcomes; (3) family factors partially have a positive and significant impact on learning outcomes; (4) school factors partially have a positive and significant impact on learning outcomes; (5) community factors partially have a positive and significant impact on learning outcomes; (6) learning motivation, family factor, school factor and community factor simultaneously have a positive and significant effect on learning outcomes.

\section{Suggestion}

Based on the results of the study, the researcher suggests: (1) for the principal to complete the school laboratory, the more classrooms have a neatly arranged desk chair for more school support. In addition, it is expected to create a classroom away from the crowd so it will be conducive to the learning process. As for teachers are advised to always come on time at the time of learning will begin so that the implementation of learning can run in accordance with predetermined time allocation so that indirectly teachers will form learners will be more disciplined; (2) for learners is suggested to be more enthusiasm to learn if get praise and reward because it is a form of appreciation to motivate learners to learn more so that learning result awake and increase. In addition, it is advisable even though no test will take place learners keep learn to prepare for future lessons. Learners are advised to follow the activities in the community so that learners have more knowledge so as to support the socialization and learning outcomes; (3) it is recommended for parents not to get learners to do other work while studying at home, so that learners are not disturbed and stay focused while studying. In addition, parents are invited to create an atmosphere of home study environment that supports learning, so that learners can learn quietly; (4) For further researchers who are interested in continuing this research, it should be further research on other variables that influence learners' learning outcomes other than learning motivation, family factors, school factors and community factors such as talent, interest, learning style, attention, motives, and readiness.

\section{REFERENCES}

Adeyemo, S.A. 2012. The Relationship between School Environments, Student Approaches to Learning and Their Academic Achievement in Senior Secondary School Physics. International Journal of Education Research and Technology, (Online), 3 (1): 21-26, (soeagra.com/ijert.htm), accessed February 5, 2017.

Ahmadi \& Supriyono. 2008. Learning Psychology. Jakarta: PT. Asdi Mahasatya. (Indonesian Origin). 
Daud, F. 2012. The Influence of Emotional Intelligence (EQ) and Learning Motivation on Biology Learning Outcomes of SMA Negeri 3 Palopo State Students. Journal of Education and Learning, (Online), 19 (2): 243-255, (http://journal.um.ac.id), accessed December 26, 2016. (Indonesian Origin).

Florescu, 0. 2014. Positive and Negative Influence of the Mass Media upon Education. Social and Behavioral Sciences, (Online), 149: 349-353, (www.sciencedirect.com) accessed June 6, 2016.

Hamalik, O. 2008. Teaching and Learning Process. Jakarta: PT. Earth Script. (Indonesian Origin).

Hasanah, B. 2014. The Effect of Family Environment on Student Learning Outcomes in Geography Subjects at SMA Negeri 1 Marawola. E-Journal Geo-Tadulako UNTAD, (Online), 2 (3): 1-13, (http://jurnal.untad.ac.id), accessed December 26, 2016. (Indonesian Origin).

Herera, A. 2013. Motivation Learning and Attention Parents Against Student Learning Results. Journal of Economic Education, (Online), 5 (3): 191-198, (http://ejournal.unesa.ac.id), accessed December 21, 2016. (Indonesian Origin).

Hoofmann, K.F., Huff, J.D., \& Patterson. US. 2009. Elementary teachers' use and perception of rewards in the classroom. Teaching and Teacher Education, (Online), 25 (6): 843-849, (www.sciencedirect.com), accessed June 5, 2016. (Indonesian Origin).

Kartika, D. 2013. The Influence of Learning Habit and Learning Environment on Students' Learning Outcomes in Economy Class X in SMA Negeri 1 Jombang. Journal of Economic Education, (Online), 1 (3), (http://ejournal.unesa.ac.id), accessed December 21, 2016. (Indonesian Origin).

Khafid \& Suroso. 2007. The Effect of Learning Discipline and Family Environment on Economic Learning Results. Journal of Economic Education, (Online), 2 (2): 185-204, (https://journal.unnes.ac.id), accessed February 5, 2017. (Indonesian Origin).

Mukhlas, S., Wahyuni, S. \& Areva, D. 2014. The Effect of School Environment and Parents' Revenues on Students Economic Learning Results Class XI SMA Negeri 5 Solok Selatan. Journal of Economic Education, (Online), 1 (1): 17-16, (http://id.portalgaruda.org), accessed February 5, 2017. (Indonesian Origin).

Mustafa, M.B., Nasir, R., \& Yusooff, F. 2010. Parental Support, Personality, Self-Efficacy and Depression among Medical Students. Procedia Social and Behavioral Sciences, (Online), 7 (C): 419-424, (www.sciencedirect.com) accessed June 5, 2016. (Indonesian Origin).

Ngoun, S. 2012. Parental Involvement and Students Achievement in Cambodia Focusing on Parental Resourcing of Public Schooling. International Journal of Educational Research, (Online), 52: 213-224, (www.sciencedirect.com) accessed June 5, 2016. 
Prawira, P.A. 2012. Educational Psychology In A New Perspective. Maguwoharjo. ArRuzz Media. (Indonesian Origin).

Rahayu, M. 2013. Influence of Interest and Motivation Learning Against Student Learning Outcomes at SMK Ketintang Surabaya. Journal of Accounting Education, (Online), 1 (3): 1-17, (http://ejournal.unesa.ac.id), accessed December 21, 2016. (Indonesian Origin).

Sanchez, C.A.G., Gonzalez, B.S.G., \& Martines, C.J.L. 2013. The Impact of Teacher-Student Relationships on EFL Learning. A Colombian Journal for Teachers of English, (Online), 20: 116-129, (www.files.eric.ed.gov.com) accessed June 6, 2016. (Indonesian Origin).

Saputro \& Pardiman. 2012. The Effect of Learning and Pyles Discipline on Peer Achievement of Student Learning Achievement of Accounting Education Study Program 2009 Faculty of Economics, State University of Yogyakarta. Journal of Accounting Indonesia, (Online), 10 (1): 78-97, (www.undana.ac.id) accessed June 6, 2016. (Indonesian Origin).

Schneider, M. 2002. Do School Facilities Affect Academic Outcomes. National Institute of Building Sciences, (Online), 1-24, (www.ncef.org/pubs/outcomes.pdf) accessed June 6, 2016. (Indonesian Origin).

Sholihah, A. \& Kurniawan, R.Y. 2016. Analysis of the Effect of Learning Motivation and Learning Environment on Learning Outcomes. Journal of Economic Education, (Online), 4 (3): 1: 5, (http://ejournal.unesa.ac.id), accessed March 5, 2017. (Indonesian Origin).

Slameto. 2010. Learning and Factors Affecting. Jakarta: Rineka Cipta. (Indonesian Origin).

Suharsaputra, U. 2014. Educational Research Methods (Quantitative, Qualitative, and Action). Bandung: PT Refika Aditama. (Indonesian Origin).

Suprijono, A. 2012. Cooperative Learning. Yogyakarta: Student Literature. (Indonesian Origin).

Syah, M. 2014. Educational Psychology. Bandung: PT. Youth Rosdakarya. (Indonesian Origin).

Tirtarahardja, U. \& La Sulo, S.L. 2005. Introduction to Education. Jakarta: PT. Rineka Cipta.

Tuncel, H. 2015. The Relationship between self-confidence and learning turkish as a foreign language. Educational Research and Reviews, (Online), 10 (18): 25752589, (www.academicjournals.org) accessed June 5, 2016. (Indonesian Origin).

Uno, H.B. 2011. Motivation Theory and its Measurement. Jakarta: PT. Earth Script. (Indonesian Origin). 